\title{
A Model of Education and Struggle of Social Status of Rural Women in Practical Politics at Bali Province
}

\author{
I Nyoman Jampel' ${ }^{1}$ I Wayan Lasmawan ${ }^{2}$ \\ Universitas Pendidikan Ganesha, Bali, Indonesia \\ Email: jampel@undiksha.ac.id, wayan.lasmawan@undiksha.ac.id
}

\begin{abstract}
The target of this study was to find out a model of political education for rural women in the province of Bali based on the wisdom of local cultural values. For the first year (2012), the product of this study consisted of: the constellation of practical politics of Bali woman profile, the draft of a model-based political education gender equality, gender mainstreaming draft models for Bali women in the political, scientific articles published in accredited journals. Overall the research data was analyzed using descriptive qualitative analysis techniques and statistical analysis to test the effectiveness of the political education model for rural women in Bali. Based on the overall research process, it gained some critical issues related to gender mainstreaming in politics at the indigenous Bali as a conclusion of this study, namely: 1) the pattern of communication and daily activity of customary village communities, the role of women's political participation tends to be low Bali. It is mostly contributed by the application of patriarchal ideology, an ideology of kinship that puts men as central ownership of the rights and obligations of the public at the level of everyday life. So that the position and status of women are subordinated. (2) The status and role of women in politics so marginalized activity, except in some aspects that still exist within the family environment, as can be seen in symbolic meaning for the name Pungkusan each nuclear family. (3) Climate and communication patterns of family life, customary village, and administrative village, the school does not support the process of political education for indigenous Balinese women to achieve improvement. (4) The customary village as the highest symbolism level of indigenous Balinese, structurally, yet real activity concerning the political education of the girls. (5) The process of the formation of Indonesian civil society, in conjunction with the purpose and characteristics of the indigenous Balinese customary village, turned out to be quite relevant in creating a climate of gender equality.
\end{abstract}

Keywords: Political Education; Balinese Women; Gender Equality; Practical Politic

\section{Introduction}

The struggle to mainstream equality of power relations between women and men (gender) in the bureaucracy to change policies is not an easy task. Especially if it is related to religious values that are believed to be a single truth. "I received many threats and terror and career stagnation. However, I did not back down", said Farisa (2006), a researcher and member of the Department of Religion's Gender Mainstreaming Working Group at a seminar on gender in a bureaucratic format. It also goes on to say that: in fact, "many old books support equality, but they have never been brought up." Thus, religious interpretations can be used as a political tool to dominate certain groups.

History has recorded, so severe and complicated the struggle of women to be able to align themselves with men in a community. Since 350 BC, Aristotle, in his treatise entitled "Politics," stated that women, children, and slaves were not citizens. This fact has been passed down for centuries in the constellation of society. It causes women to remain second-class citizens amid the progress of their society.

The door to "equality begins to open when the history of male chauvinism begins to be threatened, with the birth of various women's movements that began in the American and European regions, which eventually gave birth to various dilemmas in society. In the Western world, there is a Feminism movement, which can be classified into three groups, namely liberal feminists, radical feminists, and socialist feminists (Moraless, 2004). The aim is to make women aware of their rights, and they must demand emancipation, carried out by confronting men. The main focus of this research is the development of a model of political education and gender mainstreaming of women in the political field, especially for rural 
communities in the Province of Bali. Related to this, in detail, the specific objectives of this study can be described as follows: (1) Identifying, formulating, and mapping the basic concepts of political education that have been and are being carried out by local governments, political institutions, custom institutions, and non-governmental organizations community, both programmed and personal (need assessment). (2) Formulating and integrating the socio-cultural characteristics, and needs of Balinese women in politics, to realize optimal understanding and awareness of rural women, about political concepts and practices in their respective regions. (3) Developing a new approach to empowering women in politics, by accommodating the existence of local institutions, the cultural values of the local community, the needs and political orientation of the local community, and the formal institutions of the local regency/city government. (4) Developing a social engineering model of empowering rural women in politics, with the involvement of customary village (Desa adat) as a symbolism of the strength and integrity of customary village in every Balinese Hindu community. (5) Building social networks for the alleviation of political blindness among rural communities in Bali, through the synergy of potential and resources between campus world (research institution, customary village, regency/city government, and non-governmental organization in each research location.

At the seminar on: "Women in Bureaucratic Format, concluded that: so far the law has been used as a tool to define the power of certain groups to limit the space for women, not responsive to women's problems, including crimes against women's humanity (Sulistyowati, 2006). The issue of women is very vulnerable to be entered and made a political issue because political symbolization is attached to the sexuality of the body and the existence of women. Related to this, Farisa (2006), a social researcher who focuses on women's issues, reminds the importance of legal reform to achieve gender equality but must be aware of the draft law is laden with interests to rule.

The openness of the role of women in political contests first appeared and interpreted in Islamic sharia, which explains the sharia rules regarding men and women (Ansyar, 2006). However, this fact cannot be translated as equality treatment between men and women in the political arena. The new Sharia reflects that there is a problem of equality between men and women in the world of politics, which requires a solution. According to Ansyar (2006), the question of equality or lack of equality between men and women is not something that should be discussed in the Islamic world, because it is an expression that is not contained in Islamic legislation. Concerning the prepositions put forward by Ansyar above, Farisa (2006) states that equality between men and women in the political world, is not a matter for debate, nor is it a problem that is a subject in the Islamic social system. According to Farisa (2006), women become equal with men, or men become equal with women in political eyes, is not an urgent matter, which has influenced social life broadly, and is not a phenomenon that should be present in Islamic life. However, it is an expression that only exists in the Western world. This psychological condition is not found at all in the Muslim community, except for those who imitate western culture, which means it has violated the natural rights of women themselves in their capacity as human beings. This phenomenon is for some people of the western mindset, calling it restitution (recovery) of rights that were previously not restored yet (Ansyar, 2006).

In line with the generalization of gender equality in politics, the Bali Aga (a community which is a community that is independent of the "descendant of emigrant Majapahit) has believed that the women are a community that must always think and act in the interests of the community and its essential beliefs so that other issues including politics will follow and adapt to the conditions and interests that accompany it (Arga, 2003). Thus, Balinese society is currently positioning women are equal before God so that women are also permitted and encouraged to participate in politics as long as it does not jeopardize their primary duties as wives and mothers. In line with this, Islam also allows a woman to participate in politics, as long as she does not neglect her primary duties as a husband's companion. In Islam, a woman should deliver da'wah and carry out rules or governance (Ansyar, 2006). However, the contribution of women, according to Islamic Sharia, cannot be equated as men. 
According to Bae (2002), there are several things needed to support equal opportunities for women in politics with men, namely: support from both superiors and fellow female politicians, the need for women to equip themselves with various skills and build themselves to commit on their work. It is essential because sometimes, the political practice requires sacrifice, both individual and family. Women are also required to improve their abilities in courage and self-managerial and the ability to produce political work that can be known to others. In other words, these factors are needed to improve bargaining positions for women in politics (Orr, 2002).

Women are the organizers of the household, forming the nation and the world. "You are mothers who foster generations, where the principle of womanhood is expressed as an illusion imposed by God on Himself, as energy to equip Himself, on His own will, and this is the "virtual form of feminism" (Rg.Weda, Sloka XXI-17). This concept causes women to be seen as a manifestation of God's power in the Balinese Hindu cultural construct. A woman is a faithful companion to a man, and his luck, a woman, is a mystery, a miracle, a manifestation and principle that is protective of a man's household, a source of luck, and light that illuminates his home (Rg.Weda, Sloka XX-21).

It is due to how loaded men rarely match the woman's nature with fortitude, patience, and pure love, and their ability to control themselves. In the ideal concept of Hindu, women are role models and guides in taking spiritual life, because pure love and selflessness are inherited in women so that they can bring comfort to men. According to Bawa (2005), in Balinese society, women who are knowledgeable, cultured, bound by love, and always alert to consider whether their words and deeds are in harmony with dharma, and such women are Goddess Laksmi, Goddess of Wealth. They bring joy and luck to the household, the house where the husband and wife are bound to one another by pure love, the place where both are absorbed in reading books on spiritual food, where the name of the Lord is always sung, and His glory is always remembered, that kind of household is genuinely God's place.

A woman who is bound to her husband by love is truly a rare flower that emits fragrance (Rg.Weda, Sloka XXII-33). Furthermore, it is also stated that women are jewels who radiate light in the family, a wife who has virtue and exemplary for her child and husband, truly is a brilliant gem in the eyes of the world and before God as their creator. According to Bagus (2001), several women position themselves as "dive or rays for the lives of their people, namely: the attitude of modesty, humility, fortitude, and devotion to God, all of which are authentic ornaments for women in the level of Balinese Hindu culture.

At the level of Balinese culture, at home, women are respected as Goddess Laksmi, as companions in pilgrimage to God and pure self-awareness, and as household fragrances (Bagus, 2001). Virtue and purity are the ideal potentials for every Hindu woman. Through the strength that comes from within themselves, and the virtues they have, they can achieve anything, because virtue and purity are women's crowns, and that is where the virtues of women are most praised before Balinese Hindu culture. The benefits arising from being and the role they play cannot be described because purity is a breath of life for women. With virtue, holiness, and the power that comes from all that, a woman can save her husband from moral destruction, but sometimes women are morally destroyed by men (Bagus, 2001).

\section{Methods}

This research was conducted using the "Critical Ethnography Research" approach in the paradigm of qualitative research (Anderson, 1989), which emphasizes social research as a form of social and cultural criticism of society (Miles and Huberman, 1992). Through this approach system, relations were formed by using analyzing and synthesizing the interrelationship between actions, subjective experiences, and social conditions that are directly related to the research problem, namely the reconstruction of gender mainstreaming in practical politics in an actual description and narration, comprehensive, contextual, holistic, and meaningful.

The location of this research was in the Province of Bali, especially in customary villages in the Province of Bali. The selection of research areas was based more on efforts to fulfill and comprehend the data related to the focus of the research problem so that later 
reconstruction and gender formulations can be formulated in the political context in each research area, and reflect the overall Balinese community constructs. Following the type of data needed in this study, the data collection in this study adhered to the principle of "the researcher is the main research instrument" (Bogdan \& Taylor, 1975), but in its implementation, the researcher also implemented several aid data collection tools. Based on the approach and characteristics of the research, then the data analysis in this study was carried out continuously from the beginning to the end of the entire research process. The detailed process of data analysis in this study followed the stages of research analysis Critical Ethnography Research from Carspecken (1996), which includes preliminary steps, namely: (1) compiling original records, (2) preliminary reconstructive analysis, (3) dialogical data generation, (4) describing system relations, and (5) system relations as explanations of findings.

\section{Results}

The dominance of power and political role of men in the structure of the Linggih Desa Tegak and the governance structure of the Customary Village of Bali as described in Chapter IV cannot be separated from the fabric of the value system that underlies the social and cultural life of the Balinese community as a religious society that does adhere to the legal system and patriarchal culture. It means that, in the socio-cultural reality of Balinese society, the dominance of men has very high legitimacy. This dominance is very prominent in various fields of life, both at the level of the family, indigenous people, and village government. The consequences of patriarchal culture inherent in the life of indigenous village communities, it also seems to carry over in the administrative structure of the administrative village (Desa Dinas). It can be seen in the official village government structure, where there are only 2 (two) women who hold positions as head of affairs (Kaur), while men fill the rest. This reality is one proof that women in the Customary Village of Bali are marginalized in public.

In the Vedic scriptures, generally, there is no mention of a person's dignity parameters based on sex or birth. An incantation in the Rigveda states, "Stri hi Brahma Babhuvitha, the real woman is a scholar and guide (Rigveda VIII.33.19). From now on, it is mentioned in Bhagavadgita, "Kirtih Srir Vak cha Narinam Sritir Medha dDritih Kshama. "That is, among the characteristics of women, I am fame, prosperity, the subtlety of language, pleasure, intelligence, determination, and patience" (Bhg. X: 34). Based on the Scriptures above, it is clear that women have an honorable position.

The indigenous Balinese (Bali Asli) community as an autonomous community, has its socio-cultural patterns and dynamics. The family as the smallest social unit in the customary village government structure is the first and foremost institution, which is a medium for every member of the indigenous Balinese community to get to know the social and cultural environment. It means that it is through family institutions that a person will get to know the more extensive social and cultural confusion of his community. In family life, they will be introduced and taught a variety of basic concepts regarding values, norms, and customs that must be respected and implemented in the community. It is in line with what is presented by a Balinese education expert, Dantes (1989), that the family is the first and foremost environment for children in obtaining personality education and social education as well as various other life provision skills.

The indigenous Balinese community is an autonomous customary institution. It means that they have rules and authority that are intact in regulating and empowering all potentials owned by the customary village itself. The indigenous Balinese, a community that lives in a cultural setting characterized by patriarchal ideology, has a set of rights and obligations. As members of the customary village, each head of the family has the right to the village land (Tanah Paruman Desa), in the form of property, plantation, and graveyard. The acquisition of these rights must be balanced by carrying out certain obligations imposed by the customary village to each indigenous villagers.

According to the Indigenous Balinese Customary Village's Rules (Awig-Awig), customary villagers have several obligations, namely to obey all the rules that are applied in 
the customary village, so that an orderly society is formed based on the ideology of Tri Hita Karana. In this context several dimensions are covered, namely: (1) Sukerta tata Pawongan or participation in the Pawongan system, namely harmonious relations between humans and humans, (2) Sukerta tata Palemahan or participation in the Palemahan system, namely harmony in the relationship between humans and the natural environment, and (3) Sukerta tata Parhyangan or participation in the Parhyangan system, namely harmonious relationship between humans and the villages or the God.

The indigenous Balinese customary village community, as well as other communities in Indonesia, are in a gradual and sustainable process in order to build a new Indonesian society, namely civil society. Along with the reform process in Indonesia, Indonesian society is now entering the civil society process. Civil society is not something that is conceptualized or conceived, let alone the idea of import, but as stated by Suseno (in Jacob, 2000), is a factual society, not normative, desired or aspired along with the process of changing Indonesian society in the civil society movement.

The indigenous Balinese community as part of the development unit, especially as a rural community that has a set of potential that can be developed, also undergoes the process and movement of the ideals of civil society. So that in analyzing civil society movements within the Indonesian community generally and in particular community groups, the problem is not whether the community group understands or has the concept of civil society or whether the community agrees with the concept of civil society, but instead whether there is a civil society reflected in the life of the community, to what extent, and what the implications are. Therefore, concerning the civil society process, in the indigenous Balinese, the above problems will also be examined. Judging the goals of the indigenous Balinese and the joints of the dynamics of their community life in relevance to the ideals and movements of Indonesian civil society.

Equality and the expansion of dimensions of life is one of the indicators of democratization as an element of equality in politics (Tilaar, 1999). Based on the above reality, it appears that indigenous Balinese women have had an orientation and vision going forward that is in line with the spirit and characteristics of equality in politics, which is the hope of all countrymen of Indonesia. Political education is not poured from above, in terms of government interests solely, and is dominated by men, but education must be fostered from the community itself based on socio-cultural values that grow and develop in society. Indications of the above are that society is not an object of education, which only carries out the wishes of the government. However, they must be given active participation where the community has a role and contribution in each step of the education program while still upholding the principles and models of equality. Equality meant by indigenous Balinese women is that there is no longer any subordination of women by men in politics and work because essentially equality is the real need of all societies for a better and prosperous future. In this context, it does not mean that women are subordinated to men, and only waiting for mercy and demands, but that they are given the same responsibility in taking roles in all aspects of life so that there is a dual equality pattern in community life.

Political education should rely on the principles and cultural values of the community that have been understood and made orientation by members of the community following the demands of the public interest. It means that in designing and formulating policies and models of political education, the contents and values contained therein should be taken from local cultural values that qualitatively have competition power. The relevance of the indigenous Balinese women's political education process viewed from the dimensions of social, cultural, economic and strata life above with the enforcement of the pillars of equality in Indonesian politics can be interpreted from the relationship between the position and role of women in the context of family and community life in their capacity as husband's companion (male).

This pattern of relations between women and men gives the color of the life units of the local customary law community, which is an autonomous entity and participates in providing control for the implementation of governance (administrative village) in achieving common goals democratically. As an autonomous customary village unit, indeed, the family in the 
level of the indigenous Balinese community has government functions carried out based on the principle of independence in a narrow sense. Independence as an essential indicator inequality in politics can be carried out by every family in the life of the indigenous Balinese because they cannot be released from their obligations in carrying out their customary village government independently in line with the changing times.

It can be said that the family in the indigenous Balinese life level can walk and develop along with the dynamics of the times in a conducive climate without any collision. Family life, as the basis of political education for indigenous Balinese women, is an integral part of the customary village government structure. The customary village and administrative village officers say that the existence of a woman in a family in indigenous Bali has a profound social-religious meaning and function, and has a causal relationship with the existence of the customary village as an autonomous organization.

The dilemma between the political values of men and the social-religious values of women who are considered to have the same values of honor by indigenous people, as a whole is part of their activities as an integral part of the family which is the main pillar of indigenous Bali, as well as their participation in customary villages and temples. It is challenging to say that the position of indigenous Balinese women is subordinated. On the other hand, the existence and role of women in indigenous Balinese society, as well as their orientation and future vision, basically indigenous Balinese women have very high insight and expectations regarding equality and dual roles in all aspects of life with men. The process of political education undertaken by indigenous Balinese women, especially in the family environment and daily activities in the community as described above, indicates that indigenous Balinese women have played a role that refers to the realization of equality in Indonesian politics.

\section{Conclusion}

Based on the entire research process, several important things were obtained related to gender mainstreaming in the political field in the indigenous Balinese community as a conclusion of this study, consist of:

First, judging from the patterns of communication and activities of the indigenous villagers, the role of Balinese women's political participation tends to below. It is much contributed by the application of patriarchal ideology, which is a kinship ideology that places men as the central ownership of rights and public obligations at the level of daily life so that the position and status of women are subordinated. The tendency of the status and role of women who are subordinated can be known from the historical process of the development of the indigenous Balinese customary village, the position and role of women in the structure and system of customary village governance.

Second, the position and participation of women in political activities are marginalized, except in some aspects that still exist within the scope of the family environment. It can be seen in the symbolic meaning that is in the name of the Pungkusan of each nuclear family. The position of women is politically, very marginalized, both within the scope of the family, customary villages, and practical political activities.

Third, the climate and communication patterns of family life, customary villages, administrative villages, and schools do not support the process of political education for indigenous Balinese women to achieve improvement. In this context, women are always marginalized, both physically and psychologically. Nevertheless, amid that dilemma, it can be seen that the original Balinese women accepted the marginalization consciously and naturally. It cannot be separated from the cultural value system of the indigenous Balinese society, which is oriented towards religio-cosmos so that it places the lowest political orientation of women's values after religious, socio-economic, and autonomous values as a republic.

Fourth, the customary village as the highest symbolism in the level of indigenous Balinese structurally has not carried out any real activities concerning the political education of its women. It cannot be separated from the existence of a patriarchal dogma that has indeed been attached to the existence of indigenous Balinese customary villages. On the 
other hand, in the life of the indigenous Balinese, there has begun to be openness, especially in the youth, where women have begun to dare to come out of patriarchal patrons, such as in determining choices during national election or village head election.

Fifth, permanently, there are no significant differences between research location concerning the model of gender sensitization and awareness, because sociologically between indigenous Balinese villages have cultural, ideological similarities, so patriarchal culture has become an integral part of their social and political activities. However, on the other hand, concerning the mastery of human resources, or family modality, women are given a specific portion dominantly, such as taking care of children, family spiritual activities, fraternity, and other activities that support her husband before the customary village. The process of the formation of Indonesian civil society, about the aims and characteristics of the indigenous Balinese customary village, turned out to be quite relevant in creating a climate of gender equality.

\section{References}

Abbas, A. (2006). Kesetaraan gender dan pergulatan sosial-ekonomi masyarakat pedesaan. Denpasar: PT. Pustaka Bali Post.

Anderson, B. (1989). Imagined Community (Komunitas-Komunitas Terbayang). Jakarta: Insist.

Ansyar, L (2006). Kebebasan Wanita Tahrirul-Ma'rah fi 'Ashrir-Risalah (penerjemah: Drs. As'ad Yasin). Jakarta: Gema Insani Press.

Ardita, G.P. (2005). Kedudukan dan Peranan Wanita dalam Lembaga Politik. (Laporan Penelitian). Denpasar: Universitas Udayana.

Arga, I.M. (2003). Perempuan Bali dan Pola Ketergantungan Politik, Citra Wanita dan Kekuasaan. Surabaya: Obor Jaya.

Bagus, D.G. (2001). A Study on Customs Pertaining to Twins in Bali. New York: Columbia University Press.

Bawa, A (2006). Bali Pada Era Globalissai Pulau Seribu Pura Tidak Seindah Penampilannya. Yogyakarta: LkiS.

Bae, D. J. (2002). Gender and Political Participant. USA: Open University.

Bogdan dan Taylor. 1975. Metodologi Penelitian Kualitatif. Bandung: Remadja Karya

Carspecken, P.F. (1996). Critical Ethnography in Educational Research: A Theoretical and Practical Guide. New York and Londen: Routledge.

Farisa, A. (2006). Wanita Indonesia dan Kesempatan Pengembanagn Karis dalam Dunia Pendidikan Tinggi. Jogjakarta: LP3IS Press.

Foster, Nick. (2003). A case study of Women Academics, Views on Equal Opportunities Career prospects and Work-Family Conflicts in A British University, Women in Management Review, vol 15. no.7, pp. 316-330.

Harsiwi, T.A.M. dan B. Linggar Yekti N, (2003). Kesetaraan Kesempatan, Prospek Karir, dan Konflik Kerja-Keluarga Akademisi Wanita pada Perguruan Tinggi Swasta di Kopertis Wilayah V Daerah Istimewa Yogyakarta dan Kopertis Wilayah VI Jawa Tengah, (Hasil Penelitian Kajian Wanita), Direktorat Jenderal Pendidikan Tinggi, Departemen Pendidikan Nasional.

Hunterwill, J. (2007). The Grand Theory of Politic. USA: McMillan, co.

Ibran, T.O. (2005). Kajian Wanita dalam Pembangunan. Jakarta: Yayasan Obor Indonesia.

Kaler, I. G. K. (2003). Butir-butir Tercecer tentang Adat Bali Jilid I. Denpasar: Bali Agung.

Kantor Menteri Negara Kependudukan dan Lingkungan Hidup. (2001). Mobilitas Tenaga Kerja Wanita di Indonesia. Jakarta

Lasmawan, I.W. (2005). Perempuan Malam di Kota Singaraja: Studi Eksploratif terhadap penjaja seks komersial di Kota Singaraja: (Laporan Penelitian). Undiksha.

Lasmawan, I.W. (2006). Eksistensi Wanita dalam Struktur Masyarakat Tradisional Bali. (Laporan Penelitian). Undiksha

Lausiana, R. (2005), "Jobs and Gender: How are Women Doing, University Publication Office, Hongkong, didownload dari www.cityu.edu.hk pada tanggal 10 Maret 2002. 
Lubis, M.W. (2005). "Situation of Women in Scientific Research in Australia: Equal Opportunity is Not a Strong Enough Tool," Melbourne, Australia.

McTitto, C. (2005). "Adat and Dinas: Village and State in Contemporary Bali. Dalam Hildred Geertz (ed), State, and society in Bali. Leiden: KLTLV Press.

Orr A. (2002). The importance of fruit fly taxonomy in Indonesia. Makalah seminar Puslitbangtan

Sulistyowati, Y., 2006. Pengaruh Pemberian Likopen terhadap Status Antioksidan (Vitamin C, Vitamin E dan Gluthathion Peroksidase) Tikus (Rattus norvegicus galur Sprague Dawley) Hiperkolesterolemik. Tesis. Program Studi Magister IImu Biomedik. Universitas Diponegoro. Semarang.

Tilaar. 1999. Beberapa Agenda Reformasi Pendidikan Nasional dalam Perspektif Abad 21. Jakarta: Tera Indonesia. 